\title{
Perception of the Quality of Life of Tobacco Growers Exposed to Pesticides: Emphasis on Health, Hearing, and Working Conditions
}

\author{
Ana Maria de Barros Cazé ${ }^{1}$ Adriana Bender Moreira de Lacerda ${ }^{1,2}$ Débora Lüders ${ }^{1}$ Juliana De Conto ${ }^{3}$ \\ Jair Marques ${ }^{1}$ Tony Leroux ${ }^{2}$ \\ ${ }^{1}$ Department of Communication Disorders, Universidade Tuiuti do \\ Paraná (UTP), Curitiba, PR, Brazil \\ 2 École d'Orthophonie et d'Audiologie, Université de Montréal, \\ Montréal, QC, Canada \begin{abstract}
PhD, Universidade Tuiuti do Paraná (UTP), Rua Sidney Antonio Rangel Santos, 238, Santo Inácio, Curitiba, PR, 82010-330, Brazil (e-mail: adriana.lacerda@utp.br).
\end{abstract} \\ Address for correspondence Adriana Bender Moreira de Lacerda,
}

${ }^{3}$ Department of Speech Therapy, UNICENTRO, Irati, PR, Brazil

Int Arch Otorhinolaryngol 2019;23:50-59.

\begin{abstract}
Introduction Tobacco farming exposes workers to various health risks due to the high application of pesticides needed to control pests, weeds and fungal diseases that prevent the tobacco plant growth.

Objective To analyze the perception of the quality of life of tobacco growers exposed to pesticides, with emphasis on general health, hearing, and working conditions.

Method This is a descriptive, cross-sectional study using a quantitative approach with farmers from southern Brazil. Data were collected from November of 2012 to November of 2014. For data collection, we opted for the 36-item short form health survey (SF-36) questionnaire, and a questionnaire with closed questions about health, hearing and working conditions. We evaluated a total of 78 subjects; the study group, made up of 40 tobacco farmers exposed to pesticides, and a control group of 38 participants without occupational exposure to pesticides. Both groups are residents of the same municipality, and users of the federal public health system.

Results The results showed that tobacco growers had lower quality of life scores compared with the control group. Significant differences were observed in the areas of

Keywords

- tobacco

- pesticides

- hearing

- quality of life pain and general health. There were correlations between physical elements and chronic diseases; hearing complaints and a lack of personal protective equipment use, occupation and hearing complaints, as well as general health and hearing complaints. Conclusion Tobacco farming is a risky activity for general and hearing health, and it can impact the quality of life of those working in this field.
\end{abstract}

\section{Introduction}

According to the dossier prepared by the Brazilian Association of PublicHealth, ${ }^{1}$ Brazil is the largest consumer of pesticides in the world. The State of Paraná is the third largest consumer of pesticides in Brazil. ${ }^{2}$ The massive use of pesticides brings about serious problems to the health of workers and the whole population, as well as causing

received

June 2, 2017

accepted

December 21, 2017

published online

July 5, 2018 damage to the environment via the degradation of nonrenewable natural resources, imbalance and destruction of fauna and flora, and water, soil, and air pollution.

Brazil is the second largest tobacco producer in the world, and ranks first in tobacco exports. ${ }^{3}$ The work done by tobacco growers on their farms is little mechanized, and the data characterize it as a tiresome and stressful activity.
Copyright $\odot 2019$ by Thieme Revinter

Publicações Ltda, Rio de Janeiro, Brazil
License terms

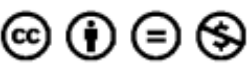


Tobacco farming exposes workers and their families to various risks due to the high application of pesticides needed to control pests, weeds and fungal diseases that prevent tobacco growth. ${ }^{4-6}$

Studies have shown that pesticides can cause long-term deleterious effects on the health of workers and can impact people's quality of life. The consequences due to exposure to pesticides are: cancer, liver damage, kidney damage, nervous system disorders, male infertility, allergic reactions, irreversible pulmonary fibrosis, and hyperglycemia. ${ }^{7-11}$

Some studies have shown that, in humans, exposure to pesticides can induce alterations in the peripheral and central auditory system as well as in the vestibular system. ${ }^{12}$

Contamination can occur through ingestion, inhalation, as well as through the eyes and skin contact. In addition, it can cause damage to the environment via the degradation of nonrenewable natural resources, imbalance and destruction of fauna and flora, as well as water, soil, and air pollution. ${ }^{2}$

The impact of organophosphate and carbamate class insecticides on general and auditory health should be noted. These insecticides act in the body by inhibiting the enzyme called acetylcholinesterase, whose function is the degradation of the neurotransmitter acetylcholine, which is responsible for transmitting impulses in the central and peripheral nervous systems. Once inhibited, this enzyme cannot degrade acetylcholine, which accumulates in the synapses, resulting in increased stimulation of the effector organ. The central nervous system signs and symptoms are due to the presence of muscarinic (in smooth muscle, cardiac fibers and exocrine glands) and nicotinic receptors (muscles skeletal and autonomic ganglia). Once exposed to organophosphates, such inhibition is considered irreversible, but exposure to carbamates is considered reversible, since it allows for faster recovery of cholinesterase. ${ }^{13}$

The concept of quality of life used in the study was established based on the proposal of the World Health Organization (WHO), which defines it as an individual's perception of their position in life within the context of the culture and value systems in which they live and in relation to their goals, expectations, standards and concerns. ${ }^{14}$

Also, according to the WHO, the quality of life reflects the subjectivity within the cultural context, and will vary for each person depending on their goals and expectations. Some aspects are common and universal, such as physical and psychological well-being, social relationships, the environment, the level of independence, and personal beliefs or religion. $^{15}$

Measures of health-related quality of life (HRQOL) are important tools for assessing heath, identifying disparities, and evaluating health interventions. The generic multidimensional 36-item short form health survey (SF-36) is a selfassessment questionnaire designed for use across a wide range of chronic disease populations. ${ }^{16}$

Studies on HRQOL within the field of audiology are generally sparse and focus mostly on the elderly section of the population. ${ }^{17}$

Given the above, the objective of this study was to analyze the perception of tobacco growers exposed to pesticides on their quality of life, with an emphasis on general health, hearing, and working conditions.

\section{Method}

This is a descriptive, cross-sectional study with a quantitative approach, performed in the Rio Azul municipality in the state of Paraná, with tobacco farmers and city dwellers. It was approved by the Ethics Committee in Human and Animal Research from Unicentro, Opinion 023/2011, and the Ethics Committee in Human and Animal Research of Centre for Interdisciplinary Research in Rehabilitation - CRIR, under the CRIR-428-0409.

Data were collected from November of 2012 to November of 2014. All participants signed a consent form.

Included in the study group were tobacco growers who had at least one case of pesticide poisoning in the family, and their family members above the age of 18 , all users of the Brazil public health system. ${ }^{18}$

Included in the control group were other workers, not farmers and with no occupational exposure to pesticides, over 18 years of age, all Brazilian public health care system users.

Those under the age of 18 , and individuals who did not agree to participate in the study were excluded.

\section{Participants}

\section{Study Group}

The sample consisted of 40 tobacco farmers exposed to a mixture of insecticides, pesticides, fungicides, herbicides and miticides, $44 \%$ were female and $56 \%$ were male, aged 18-68 years (mean 39.2 years).

As for the general health conditions reported by the study group, 31 subjects stated having chronic diseases, such as respiratory diseases $(n=5)$, headaches $(n=4)$, hypertension $(n=2)$, diabetes $(n=2)$, renal disease $(n=2)$, problems with the thyroid gland $(n=1)$, arthritis $(n=1)$, heart disease $(n=1)$, and anxiety $(n=1)$.

As for hearing health, it is important to note that 22 subjects mentioned hearing complaints, and some reported more than one symptom. Among the complaints were intolerance to loud sounds $(n=7)$, ear infections $(n=7)$, difficulty hearing $(n=5)$, ear fullness $(n=5)$, tinnitus $(n=5)$, pruritus $(n=4)$, and dizziness $(n=1)$.

As for the growers' current situation in farming, 52.63\% still plant tobacco, $39.47 \%$ have planted tobacco and now plant another crop, and $7.89 \%$ are occasional workers (working per day only at harvest time). - Table 1 shows the relationship of pesticide exposure and use of personal protective equipment (PPE) among tobacco growers. The personal protective equipment utilized included leather boots and latex gloves, caps, masks without a filter, and overalls. (-Fig. 1)

\section{Control Group}

The control group consisted of 38 workers not occupationally exposed to pesticides, $57 \%$ were female and $42 \%$ were male, aged 18-68 years (mean 41.4 years). 
Table 1 Relationship between pesticide exposure and use of personal protective equipment (PPE) among tobacco growers

\begin{tabular}{|c|c|c|}
\hline Exposure & Frequency & $\%$ \\
\hline \multicolumn{3}{|l|}{ Time (years) } \\
\hline Less than 5 & 6 & 15.79 \\
\hline From 5 to 10 & 2 & 5.26 \\
\hline From 10 to 20 & 11 & 28.95 \\
\hline More than 30 & 19 & 50.00 \\
\hline \multicolumn{3}{|l|}{ Occupation } \\
\hline No answer & 2 & 5.26 \\
\hline $\begin{array}{l}\text { Various, including } \\
\text { application }\end{array}$ & 25 & 66.79 \\
\hline $\begin{array}{l}\text { Various, except } \\
\text { application }\end{array}$ & 5 & 13.16 \\
\hline Cultivation & 1 & 2.63 \\
\hline Cultivation and harvest & 1 & 2.63 \\
\hline $\begin{array}{l}\text { Planting and handling of } \\
\text { tobacco leaves }\end{array}$ & 1 & 2.63 \\
\hline Equipment washing & 1 & 2.63 \\
\hline $\begin{array}{l}\text { Harvest and handling of } \\
\text { tobacco leaves }\end{array}$ & 1 & 2.63 \\
\hline $\begin{array}{l}\text { Handling of tobacco } \\
\text { leaves }\end{array}$ & 1 & 2.63 \\
\hline Retired & 1 & 2.63 \\
\hline \multicolumn{3}{|l|}{ Use of PPE } \\
\hline No & 13 & 34.21 \\
\hline Yes & 23 & 60.53 \\
\hline No answer & 2 & 5.26 \\
\hline \multicolumn{3}{|l|}{ Poisoning } \\
\hline No & 15 & 39.47 \\
\hline Yes & 21 & 55.26 \\
\hline No answer & 2 & 5.26 \\
\hline \multicolumn{3}{|l|}{ Pesticides } \\
\hline Yes & 36 & 89.48 \\
\hline No & 2 & 5.26 \\
\hline No answer & 2 & 5.26 \\
\hline
\end{tabular}

The control group's professions were: retired $(n=2)$, administrative assistant $(n=3)$, nursing assistant $(n=1)$, clerk $(n=3)$, merchant $(n=3)$, housekeeper $(n=4)$, housewife/ homemaker $(n=7)$, student $(n=2)$, pharmacist $(n=1)$, car washer $(n=3)$, carpenter $(n=1)$, driver/truck driver $(n=2)$, locksmith $(n=1)$, merchant $(1)$, teacher $(n=1)$, bricklayer $(n=2)$, and nursing technician $(n=1)$.

As for the general health conditions reported by the control group, 16 subjects reported chronic diseases like sinusitis $(n=1)$, hypertension $(n=8)$, diabetes $(n=3)$, problems in the thyroid gland $(n=2)$ arthritis $(n=1)$, heart disease $(n=1)$, anxiety $(n=2)$, anemia $(n=1)$, and dyslipidemia $(n=3)$

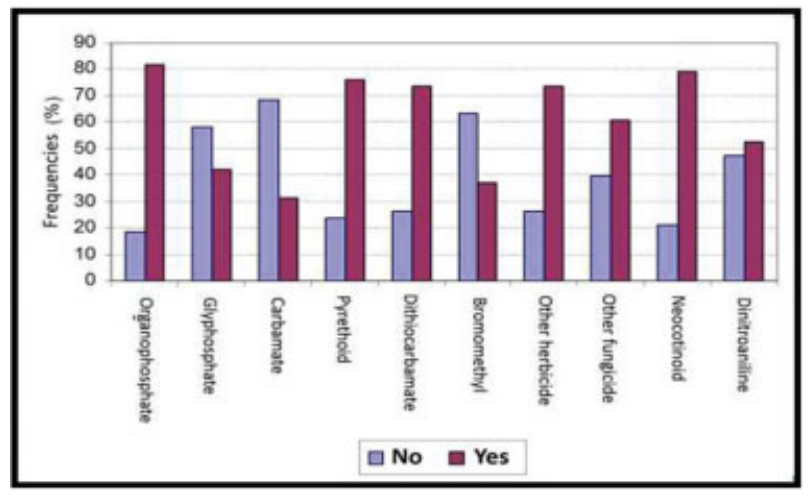

Fig. 1 Shows the distribution of stated pesticides (\%).

Regarding hearing health, it is important to point out that only 5 subjects reported hearing complaints, and some reported more than one symptom. Among these complaints were intolerance to loud sounds $(n=3)$, and difficulty hearing $(n=2)$.

\section{Procedures}

To collect data on health, hearing, and working conditions, a questionnaire containing only closed questions was chosen and prepared by the researchers. To assess the quality of life, a generic, self-perception questionnaire, the SF-36, was used and validated in Brazil. ${ }^{19}$ The method evaluates negative aspects of health, such as disease, and positive aspects of welfare. According to Dantas et $\mathrm{al}^{20}$ $34 \%$ of the scientific studies on the quality of life from 1999 to 2001 used the SF-36 questionnaire and deemed it efficient.

The SF-36 is a questionnaire containing 36 questions divided into sections related to physical activity, social activity, limitations from physical disability, limitations for emotional capacity, mental health, vitality, pain, health perception in general, and perception of improvement in specified health problems. The score ranges from 0 to 100 the higher the number, the better the subject's perception of the quality of life.

The application of the SF-36 questionnaire to the groups, study and control, was held at the Brazil public health system in the city of Rio Azul, Paraná, in the form of an interview.

\section{Data Analyses}

The statistical analysis of the present study was performed with the use of descriptive methods (tables for mean, minimum, maximum and standard deviation) and inferential methods: The Student $t$-test, Fisher exact test and chi-square test were used at a significance level of 0.05 .

The analysis of the SF-36 was divided into the following sections: physical functioning, role limitations due to physical health, pain, general health, vitality, social functioning, role limitations due to emotional problems, and mental health. Next, the analysis was performed in three steps. First the data was weighted. Next, the raw scale was calculated 
because the total score has no measurable scale. Then, for each section, there is a value within the range defined as answered in the questionnaire. This value was subtracted from the lower limit. That figure was calculated based on a scale whose resulting values are multiplied by 100 (one hundred) and divided by the variation (score range).

It should be noted that question number two on the SF-36 is not part of the calculation for any section and is used to assess how much the individual's health is better or worse when compared with one year ago.

\section{Results}

Regarding the quality of life of the participants, - Table 2 shows the scores obtained in each of the sections assessed by the SF-36 questionnaire. It appears that there are significant differences in the average of the two groups for the sections: "pain" and "general health." It is found that, in all sections, the averages of the control group are always higher; however, significance occurs only in the two sections mentioned above.

- Table 3 shows the analysis of the sections and the presence of chronic diseases in the tobacco growers group. A statistically significant relationship was found between the section "role limitations due to physical health" and chronic diseases.

- Table 4 shows the correlation between the sections and hearing complaints in the tobacco growers group. It appears that there is a significant relationship between the sections "role limitations due to physical health" and "general health" with hearing complaints.
In the analysis of the correlation of the questionnaire sections and the occupation of the study group, no significant difference ( $p \leq 0.05$ ) was found between the sections and the occupation, the sections and the type of pesticide, and the sections and the presence of contamination.

- Table 5 shows a significant difference between the "role limitations due to physical health" section and the lack of use of PPEs ( $p=0.0333$ ).

In the analysis of the correlation of the questionnaire sections and the occupation of the study group, there was no significant difference $(\mathrm{p} \leq 0,05)$ between the sections and the occupation, the sections and the type of pesticide, and the sections and the presence of contamination.

\section{Discussion}

This study aimed to analyze the perception of tobacco growers who have been exposed to pesticides regarding their quality of life, emphasizing health, hearing and working conditions.

- Table 2 shows a correspondence between the answers concerning pain and general health to be significant for the tobacco growers group compared with the control group. The results showed that tobacco growers had worse quality of life scores compared with the control group. The tobacco farmers did not realize that they could have better general health and access to better living. A study by the Brazilian Association Tobacco Growers ${ }^{3}$ states that the work done by tobacco growers on their farms is not very mechanized, characterizing it as a tiring and exhausting

Table 2 Scores on SF-36 for the study and control groups $(N=78)$

\begin{tabular}{|c|c|c|c|c|c|c|c|}
\hline Section & Group & $\mathrm{N}$ & Mean & Min. & Max. & SD & $p$ \\
\hline \multirow[t]{2}{*}{ Physical functioning } & Study & 40 & 78.38 & 0 & 100 & 26.54 & \multirow[t]{2}{*}{0.7466} \\
\hline & Control & 38 & 80.39 & 0 & 100 & 28.46 & \\
\hline \multirow{2}{*}{$\begin{array}{l}\text { Role limitations due to } \\
\text { physical health }\end{array}$} & Study & 40 & 66.88 & 0 & 100 & 40.19 & \multirow[t]{2}{*}{0.2188} \\
\hline & Control & 38 & 77.63 & 0 & 100 & 36.02 & \\
\hline \multirow[t]{2}{*}{ Pain } & Study & 40 & 61.93 & 0 & 100 & 28.71 & \multirow[t]{2}{*}{$0.0431^{*}$} \\
\hline & Control & 38 & 74.58 & 20 & 100 & 25.42 & \\
\hline \multirow[t]{2}{*}{ General health } & Study & 40 & 50.75 & 5 & 82 & 18.71 & \multirow[t]{2}{*}{0.0009} \\
\hline & Control & 38 & 66.63 & 20 & 100 & 21.74 & \\
\hline \multirow[t]{2}{*}{ Vitality } & Study & 40 & 46.75 & 10 & 75 & 16.07 & \multirow[t]{2}{*}{0.6695} \\
\hline & Control & 38 & 48.16 & 30 & 80 & 10.49 & \\
\hline \multirow[t]{2}{*}{ Social functioning } & Study & 40 & 81.56 & 0 & 100 & 24.18 & \multirow[t]{2}{*}{0.2298} \\
\hline & Control & 38 & 87.05 & 37 & 100 & 18.61 & \\
\hline \multirow{2}{*}{$\begin{array}{l}\text { Role limitations due to } \\
\text { emotional problems }\end{array}$} & Study & 40 & 75.01 & 0 & 100 & 37.55 & \multirow[t]{2}{*}{0.2047} \\
\hline & Control & 38 & 85.09 & 0 & 100 & 31.67 & \\
\hline \multirow[t]{2}{*}{ Mental health } & Study & 40 & 56.51 & 24 & 76 & 13.62 & \multirow[t]{2}{*}{0.5099} \\
\hline & Control & 38 & 58.21 & 40 & 68 & 8.46 & \\
\hline
\end{tabular}

Abbreviations: SD, standard deviation; SF-36, 36-item short form health survey.

* Student $t$-test at significance level of 0.05 . 
54 Perception of the Quality of Life of Tobacco Growers Exposed to Pesticides Cazé et al.

Table 3 Analysis of correlation between sections and chronic illness in the study groups $(N=40)$

\begin{tabular}{|c|c|c|c|c|c|}
\hline \multirow{2}{*}{$\begin{array}{l}\text { Section and } \\
\text { Chronic } \\
\text { Illness } \\
\text { (Yes/No) }\end{array}$} & \multicolumn{4}{|c|}{ Scores } & \multirow[t]{2}{*}{$p$} \\
\hline & $>25$ & $\begin{array}{l}25 \text { to } \\
49\end{array}$ & $\begin{array}{l}50 \text { to } \\
74\end{array}$ & $\begin{array}{l}75 \text { to } \\
100\end{array}$ & \\
\hline \multicolumn{6}{|c|}{ Physical functioning } \\
\hline Yes & 1 & 1 & 5 & 8 & 0.6812 \\
\hline No & 1 & 0 & 1 & 10 & \\
\hline \multicolumn{6}{|c|}{ Role limitations due to physical health } \\
\hline Yes & 6 & 1 & 1 & 7 & $0.0302^{*}$ \\
\hline No & 1 & - & 2 & 9 & \\
\hline \multicolumn{6}{|l|}{ Pain } \\
\hline Yes & 3 & 3 & 6 & 3 & 0.4113 \\
\hline No & 2 & 1 & 4 & 5 & \\
\hline \multicolumn{6}{|c|}{ General health } \\
\hline Yes & 1 & 6 & 8 & - & 0.4835 \\
\hline No & 2 & 2 & 6 & 2 & \\
\hline \multicolumn{6}{|l|}{ Vitality } \\
\hline Yes & 2 & 4 & 8 & 1 & 0.3435 \\
\hline No & 2 & 5 & 5 & - & \\
\hline \multicolumn{6}{|c|}{ Social functioning } \\
\hline Yes & 1 & - & 5 & 9 & 0.8695 \\
\hline No & - & 1 & 3 & 8 & \\
\hline \multicolumn{6}{|c|}{ Role limitations due to emotional problems } \\
\hline Yes & 3 & 1 & 2 & 9 & 0.9218 \\
\hline No & 2 & 1 & 3 & 6 & \\
\hline \multicolumn{6}{|c|}{ Mental health } \\
\hline Yes & - & 3 & 10 & 2 & 0.2650 \\
\hline No & 1 & 4 & 7 & - & \\
\hline
\end{tabular}

* Student $t$-test at significance level of 0.05 .

activity, in addition to having health risks from exposure to pesticides.

According to Yamada, ${ }^{21}$ the understanding of the risk in tobacco farming is impaired when referring to oneself. For the author, farmers of tobacco, as well as in those in other agricultural activities, do not seem to relate their work to health problems. They seem to believe that work affects the health of others and not their own health. In addition, the perception of the relationship between health and social relations is not noticeable.

When considering the quality of life as the individual's perception of their position in life within the context of culture and value systems in which they live, and in relation to their goals, expectations, standards and concerns, ${ }^{14}$ one must read the meaning of quality of life in the worker's perspective in accordance with the conditions of life that are part of their cultural tradition, and thus, apart from social
Table 4 Analysis of correlation between the sections and hearing complaints in the study groups $(N=40)$

\begin{tabular}{|c|c|c|c|c|c|}
\hline \multirow{2}{*}{$\begin{array}{l}\text { Section and } \\
\text { Hearing } \\
\text { Complaint } \\
\text { (YES/NO) }\end{array}$} & \multicolumn{4}{|c|}{ Scores } & \multirow[t]{2}{*}{$p$} \\
\hline & $>25$ & $\begin{array}{l}25 \text { to } \\
49\end{array}$ & $\begin{array}{l}50 \text { to } \\
74\end{array}$ & $\begin{array}{l}75 \text { to } \\
100\end{array}$ & \\
\hline \multicolumn{6}{|c|}{ Physical functioning } \\
\hline Yes & 3 & 1 & 5 & 13 & 0.1495 \\
\hline No & - & - & - & 10 & \\
\hline \multicolumn{6}{|c|}{ Role limitations due to physical health } \\
\hline Yes & 7 & 1 & 2 & 12 & $0.0277^{*}$ \\
\hline No & - & - & 2 & 8 & \\
\hline \multicolumn{6}{|l|}{ Pain } \\
\hline Yes & 6 & 3 & 10 & 3 & 0.0804 \\
\hline No & - & 1 & 3 & 6 & \\
\hline \multicolumn{6}{|c|}{ General health } \\
\hline Yes & 3 & 7 & 11 & 1 & $0.0101^{*}$ \\
\hline No & - & - & 7 & 3 & \\
\hline \multicolumn{6}{|l|}{ Vitality } \\
\hline Yes & 1 & 11 & 9 & 1 & 0.3291 \\
\hline No & 1 & 3 & 5 & 1 & \\
\hline \multicolumn{6}{|c|}{ Social functioning } \\
\hline Yes & 1 & 2 & 6 & 13 & 0.2200 \\
\hline No & - & - & 1 & 9 & \\
\hline \multicolumn{6}{|c|}{ Role limitations due to emotional problems } \\
\hline Yes & 4 & 2 & 4 & 12 & 0.2733 \\
\hline No & - & 1 & 1 & 8 & \\
\hline \multicolumn{6}{|c|}{ Mental health } \\
\hline Yes & - & 8 & 12 & 2 & 0.3546 \\
\hline No & - & 2 & 7 & 1 & \\
\hline
\end{tabular}

* Student $t$-test at significance level of 0.05 .

indicators used by agencies that promote health equity promotion policy for all segments of society.

It is understood that tobacco growing is an activity that is part of local tradition, responsible for the livelihood of families, and any subsequent harm it causes might not be perceived by tobacco farmers as they have grown accustomed to the activity for generations.

The perception of risks by the farmers, according study, 22 is influenced by cultural, social and economic factors that contribute to the adoption of strategies for risk adaptation. In the same vein, the study by Bedor et $\mathrm{al}^{23}$ considers that the low perception of risk by the population that is exposed to pesticides is a key issue in farming practices. According to Almeida Filho, ${ }^{24}$ the farmers do not receive the proper information to consider the impact of pesticide use on the environment and on human health, and therefore, the population overestimates the benefits of pesticides. 
Table 5 Analysis of correlation between the sections and the use of personal protective equipment in the study groups $(N=38)$

\begin{tabular}{|c|c|c|c|c|c|}
\hline \multirow{2}{*}{$\begin{array}{l}\text { Section and } \\
\text { PPE Use }\end{array}$} & \multicolumn{4}{|c|}{ Scores } & \multirow[t]{2}{*}{$p$} \\
\hline & $>25$ & $\begin{array}{l}25 \text { to } \\
49\end{array}$ & $\begin{array}{l}50 \text { to } \\
74\end{array}$ & $\begin{array}{l}75 \text { to } \\
100\end{array}$ & \\
\hline \multicolumn{6}{|c|}{ Physical functioning } \\
\hline No & - & - & 2 & - & 0.8533 \\
\hline Yes & 1 & 1 & 2 & 19 & \\
\hline \multicolumn{6}{|c|}{ Role limitations due to physical health } \\
\hline No & 1 & 1 & - & - & ${ }^{*} 0.0333$ \\
\hline Yes & 2 & 1 & 3 & 17 & \\
\hline \multicolumn{6}{|l|}{ Pain } \\
\hline No & - & 2 & - & - & 0.0500 \\
\hline Yes & 3 & 1 & 12 & 7 & \\
\hline \multicolumn{6}{|c|}{ General health } \\
\hline No & 1 & - & 1 & - & 0.6000 \\
\hline Yes & 1 & 7 & 11 & 14 & \\
\hline \multicolumn{6}{|l|}{ Vitality } \\
\hline No & 1 & - & 1 & - & 0.6967 \\
\hline Yes & 2 & 11 & 9 & 1 & \\
\hline \multicolumn{6}{|c|}{ Social functioning } \\
\hline No & - & - & 1 & 1 & 0.9200 \\
\hline Yes & - & 1 & 3 & 19 & \\
\hline \multicolumn{6}{|c|}{ Role limitations due to emotional problems } \\
\hline No & - & - & 2 & - & 0.7700 \\
\hline Yes & 1 & 2 & 4 & 16 & \\
\hline \multicolumn{6}{|l|}{ Mental health } \\
\hline No & - & 1 & 1 & - & 0.5467 \\
\hline Yes & - & 7 & 14 & 2 & \\
\hline
\end{tabular}

*Fisher exact test at a significance level of 0.05 (5\%). Among the 40 subjects in the study group, 2 did not respond to the questions on use of personal protective equipment.

According to Fleck, ${ }^{15}$ the concept of quality of life reflects the subjectivity immersed in the cultural context, and will vary for each person, depending on their goals and expectations. It is also noted that some aspects are common and universal, such as physical and psychological well-being, social relationships, the environment, level of independence, and personal beliefs or religion.

Taking into account individual health, it is assumed that not all healthy subjects are free of disease, and not all those who are free of disease are healthy. ${ }^{25}$ In everyday life, people suffering from illness, and who have disabilities or impairments, can be recognized as healthy and productive, without showing signs of functional limitations. On the other hand, some people may show signs of disabilities and impairments, as well as limitations and suffering, without any clinical evidence of disease. Therefore, besides the presence or absence of disease, one must consider the severity and complications that will interfere with the quality of life. ${ }^{26}$

- Table 3 shows that the majority of the tobacco growers got scores higher than $50 \%$ (with or without any chronic disease); however, there was a significant relationship between the "role limitations due to physical health" section and chronic diseases. In 2013, a cross-sectional study was conducted of 2,315 rural-to-urban migrant workers, and 2,347 local urban residents in the Shenzhen-Dongguan economic zone (China). The outcomes included HRQOL (measured by SF- 36) and health service utilization (selfreported). The results showed that compared with local urban residents, rural-to-urban migrant workers had lower scores in all domains of HRQOL, and were more likely to report chronic illnesses ( $9.2 \%$ versus $6.0 \%$, adjusted odds ratio $[\mathrm{OR}]=1.62,95 \% \mathrm{CI} 1.28-2.04)$ and recent two-week morbidity $(21.3 \%$ versus $5.0 \%$, adjusted $\mathrm{OR}=5.41,95 \%$ confidence interval $[\mathrm{CI}]$ 4.26-6.88). Among the individuals who reported sickness in the previous two weeks, migrant workers were much less likely to see a doctor $(32.7 \%$ versus $66.7 \%$, adjusted $\mathrm{OR}=0.21,95 \% \mathrm{CI} 0.13-0.36){ }^{27}$ These findings agree with other studies ${ }^{7-11}$ showing that exposure to pesticides can cause harmful long-term effects on the health of rural workers, and the exhausting activity of the tobacco growers can cause physical health problems too ${ }^{3}$

One study ${ }^{28}$ with tobacco growers from Pelotas showed that workers have superficial knowledge about the health risks they are exposed to in their work environment, and that PPE is not widely accepted - workers do not wear some of the equipment because they consider it uncomfortable. There is a lack of training aimed at farmers focusing on prevention of health problems and the proper handling of pesticides. $^{29}$

- Table 4 shows the relationship between the sections for "role limitations due to physical health" and "general health" regarding hearing complaints from tobacco farmers. Chia et $\mathrm{al}^{30}$ assessed the association between hearing impairment and HRQOL using the SF-36. The results showed that binaural hearing impairment was associated with poorer SF-36 scores in both physical and mental health, with poorer scores associated with more severe levels of impairment. Authors ${ }^{17}$ compared the results of the HRQOL questionnaire with the hearing handicap between two groups of employees with normal hearing (20) and aided hearing impairment (20). The HRQOL results were also compared with a normative population (597). Swedish versions of the SF-36 and the hearing handicap inventory for adults (HHIA) were used to determine the HRQOL and hearing handicap. The employees reported relatively good HRQOL in relation to the normative population, but significantly lower physical functioning and higher perceived effort than their normally-hearing peers in noisy environments. Results from the HHIA showed mild selfperceived hearing handicap. The current results demonstrate that the physical health status can be negatively affected even at a mild-moderate severity of hearing impairment, and that a higher perceived effort is reported from this group when performing a task in a noisy environment, despite the regular use of hearing aids. 
Despite the fact that the tobacco growers' hearing was not measured in this study, it is generally agreed that HRQOL measures could be useful in the audiological assessment and rehabilitation, as the generic health status measures could lack necessary sensitivity to detect everyday life difficulties that a hearing impairment may cause. ${ }^{31}$

Regarding the effects of pesticides on the auditory system, it is known that many of the pesticides used in agriculture are neurotoxic and can affect the central and peripheral nervous systems, ${ }^{32}$ leading to more serious problems than hearing loss. But also, there is evidence that hearing loss is an early manifestation of contamination. ${ }^{33}$ According to Morata, ${ }^{34}$ some pesticides and herbicides, such as organophosphates, can have a toxic effect on the auditory system.

Hwang et $\mathrm{al}^{35}$ performed a retrospective cohort study and applied a questionnaire to 1,622 residents and growers near farms exposed to pesticides (organophosphates) with questions aimed at hearing and hearing loss. They observed a higher prevalence of people with difficulty hearing in farmers who had greater exposure to pesticides, aggravated by exposure to noise.

Crawford et $\mathrm{al}^{36}$ administered questionnaires to 14,229 male pesticide applicators. The questionnaires assessed auditory complaints among individuals exposed to pesticides. Of the 14,229 pesticide applicators, 4,926 reported difficulty hearing, and the 9,303 subjects in the control group reported no difficulty hearing. The survey found that hearing loss is significantly associated with agricultural activities, suggesting that exposure to pesticides (organophosphates) increases the risk of hearing loss.

Other studies ${ }^{37-41}$ have shown that hearing damage can negatively impact the quality of life of workers exposed to pesticides.

De Sena et al $^{38}$ conducted a study with 351 adult farm workers, aged 18-59 years, of both genders, with a mean age of 33 years, and mean duration of exposure of 16 years, working currently or in the past within the agricultural sector in rural areas, with or without the use of pesticides. All workers underwent otoscopy, medical history, a questionnaire on the quality of life index, and pure tone audiometry. The authors concluded that there was an influence from the pesticides on the hearing health and the quality of life in the farm workers.

Alcarás et $\mathrm{al}^{3,39}$ evaluated the hearing of 25 workers exposed to noise and pesticides, of both genders, aged 2235 through exams for transient evoked otoacoustic emissions (TEOAE), distortion product evoked otoacoustic emissions (DPOAE), and research of the suppression effect. The results were compared with a control group of 30 subjects without exposure, of both genders, aged between 18 and 35 years. The results showed statistically significant differences between the findings of TEOAE and DPOAE, and the exposed group had worse outcomes and lower suppressing effects, suggesting that otoacoustic emissions and the suppression effect can be used in early identification of hearing loss in workers exposed to noise and pesticides.

França et $\mathrm{al}^{40}$ analyzed the auditory effects of exposure to pesticides in the central auditory system of 22 tobacco farmers, aged 20-57 years, applying auditory processing tests, the dichotic digits test (DDT) and random gap detection test (RGDT). In the DDT and RGDT, there were significant differences between the groups. Thus, it may be suggested that the auditory abilities of temporal resolution and binaural integration are impaired in tobacco farmers exposed to pesticides.

Lobato ${ }^{41}$ evaluated agricultural workers exposed to pesticides. They underwent an audiological evaluation composed of the following: a questionnaire, otoscopy, pure tone audiometry, immittance screening, high frequency audiometry, TEOAE, DPOAE, and research of the suppression effect, as well as a biological evaluation. The study results showed that exposure to pesticides can cause auditory dysfunction, both peripheral as well as central, with impairment to the basal region of the cochlea and the efferent olivocochlear system.

As to the correlation between the questionnaire sections and work, there was no significant difference between the sections and the occupation of tobacco grower ( $\mathbf{- T a b l e ~} \mathbf{1}$ ), which could suggest that any activity in tobacco farming might present a risk to health.

According to the Brazilian Association of Tobacco Growers, ${ }^{3}$ in southern Brazil tobacco farming is developed in farms that are considered small. On these farms, the burden of tobacco farming is shared by both the tobacco grower and his family, who ends up getting involved in all activities of farming and consequently is exposed to agents that can damage their health. ${ }^{26,37,42-45}$ This fact could have influenced the results of the absence of correlation between the questionnaire sections and work, that is, all activities exercised by the tobacco farmer and his family related or not to work itself, are submitted to the effects of exposure to pesticides, which would affect their quality of life.

Also, there was no significant difference between the sections and the type of pesticide (-Table 1 ), which could demonstrate the effect of the pesticide mixture on health and, therefore, on the quality of life. Soares et $\mathrm{al}^{46}$ showed that in work practices with pesticides, several substances are used simultaneously, a fact also reported by tobacco farmers interviewed in this study (-Table $\mathbf{1}$ ).

Furthermore, the use of combined substances is thoroughly discussed by Silva et $\mathrm{al}^{45}$ which explains that the addition of various chemicals can cause independent synergistic and antagonistic effects on human health, and that variables such as nutrition, alcohol abuse, and smoking can interfere with the chemicals' effects on health. Also, stress at work and elevated temperatures may contribute to the harmful effects of occupational exposure to these chemical agents, and farmers are particularly exposed to high temperatures and stress in work activities.

Moreira et $\mathrm{al}^{9}$ found the use of more than 100 different pesticide combinations and state that use of these combinations often occurs without technical guidance.

In contrast, the Pan American Health Organization ${ }^{47}$ points out that organophosphates cause the highest number of deaths and poisonings in the country, because such pesticides act as cholinesterase inhibitors and can be absorbed either by contact with the dermis, or by ingestion or inhalation. The inhibition of cholinesterase promotes the 
accumulation of acetylcholine at nerve synapses, leading to parasympathomimetic effects.

For the correlation among the sections and the presence of contamination (-Table 1), no significant differences were observed. It is known that clinical manifestations (acute or chronic), due to the lack of specific symptoms related to poisoning, make it difficult, in most cases, to establish the relationship of the type of pesticides with a causal link. ${ }^{48}$

However, acute and chronic exposure may cause various diseases, such as various types of cancer, liver damage, kidney damage, central nervous system disorders, male sterility, allergic reactions, irreversible lung fibrosis, and hyperglycemia, as well as nicotine absorption through the skin upon contact with green and damp tobacco leaves, which causes "green tobacco sickness," whose symptoms are nausea, vomiting, weakness, headache, dizziness, and may also include abdominal cramping. ${ }^{6}$

In - Table 5, significant differences were found between the physical functioning section and non-use of PPEs ( $p=0.0333$ ). Our study has shown that tobacco growers have worked for many years without using any kind of protection, and the protection used today is still not in accordance with the standards recommended by the Labor Ministry. ${ }^{49}$ A fact that can be related to findings by Czeresnia, ${ }^{26}$ who reported that, despite contact with pesticides occurring over the entire tobacco production process, it is at the stage of harvest, during the months from December to February, that the worker gets exposed the most; after all, that corresponds to the Brazilian summer, which exposes workers to high temperatures and causes greater rejection of the use of PPE.

Lima $^{50}$ reports that there is a lack of preparation of tobacco growers regarding their personal care when handling pesticides. Despite being oriented to wear PPE, they do not do so in practice. The author describes how boots and a hat were, largely, the "protective" equipment used by workers during the application of pesticides, and most discarded the use of masks or special clothing. Similar data were found in this study (-Table 1).

Given this reality, the importance of implementing health promotion projects involving a multidisciplinary team of health professionals, safety engineers, agronomists, and others should be emphasized. In addition, government surveillance and health care systems to empower the farmers should be stressed, focusing on care for general health, use of hearing protection, use of smaller amounts of pesticides or their replacement with equivalent products that are less toxic. It is also worth emphasizing the need for projects to develop planting techniques without the need for pesticides.

At this time, it is the worker's own choice as to the limits of his ability to work. However, the ability of the worker to take care of himself is a dubious idea. One can only wonder whether in fact these workers have developed the awareness to take care of themselves. There is a need to invest in actions that can reduce these workers' vulnerability to disease, and stop them from generating inability, chronic suffering and premature death in individuals and in the population at large.
The data from this study reinforce the need for control of occupational hazards, identification of illness from exposure to pesticides in tobacco farming, and empowerment and improvement of people's quality of life.

The Health Department Model for Populations Exposed to Pesticides ${ }^{51}$ and the Assessment Protocol for Chronic Pesticide Poisoning ${ }^{48}$ are intended to guide the Brazilian public health care system health diagnosis network for the care, treatment, rehabilitation, promotion, prevention, and surveillance of workers exposed to pesticides, with these documents suggested for monitoring the general health and hearing of tobacco growers.

As for empowerment and improving the population's quality of life, in the global arena, Brazil is still considered a developing country where a small portion of the population has access to the production of goods and services, and inequality impacts the quality of life, human health and environmental conditions. ${ }^{51,52}$

In this study, the SF-36 was successful in identifying the impact on the quality of life of tobacco farmers. However, one of the limitations of this study is that it depends on selfreported signs and symptoms of disease. It is suggested that studies be performed with clinical and hearing evaluations of the participants, as well as measuring the implications of harm to the quality of life.

\section{Conclusion}

It can be concluded that tobacco growers had worse scores on the perception of quality of life when compared with the control group; thereby, showing a worse quality of life. However, there was statistical significance only in relation to the sections for pain and general health. There was a statistically significant relationship between the section for role limitations due to physical health and chronic diseases ( $p=0.0302)$, hearing complaints $(p=0.0304)$, and non-use of PPEs $(p=0.0333)$. Also, a statistically significant relationship was found between the sections for physical functioning and hearing complaints $(p=0.0077)$, and the sections for general health and hearing complaints $(p=0.0100)$.

\section{References}

1 ABRASCO - Associação Brasileira de Saúde Coletiva. Um alerta sobre os impactos dos agrotóxicos na saúde [Internet]. Ed. Rio de Janeiro, abril de 2012. Available at: http://greco.ppgi.ufrj.br/ DossieVirtual/. Accessed Aug 26, 2014

2 IPARDES. Instituto Paranaense de Desenvolvimento Econômico e Social [Internet]. Anuário 2010. Available at: http://www.ipardes. pr.gov.br/anuario_2010/index.html. Accessed Aug 08, 2014

3 ASSOCIAÇÃO DOS FUMICULTORES DO BRASIL (AFUBRA). Relatório de Atividades [Internet]. 2012/ 2013. Available at: (http://www. previdenciasocial.gov.br/arquivos/office/3_081014-105206-701. pdf). Accessed Aug 26, 2014

4 BRASIL. Ministério da Saúde. Instituto Nacional de Câncer José Alencar Gomes da Silva (INCA). A interferência da indústria do tabaco: apresentação e orientações técnicas. Rio de Janeiro: MS; 2012

5 Silva JM, Novato-Silva E, Faria HP, Pinheiro TMM. Agrotóxico e trabalho: Uma combinação perigosa para a saúde do trabalhador rural. Cien Saude Colet 2005;10(04):891-904 
6 Riquinho DL, Hennington EA. Cultivo do tabaco no sul do Brasil: doença da folha verde e outros agravos à saúde. Cien Saude Colet 2014;19(12):4797-4808 Available at: http://www.scielo.br/pdf/ csc/v19n12/1413-8123-csc-19-12-04797.pdf. Accessed May 12, 2018

7 Baldi I, Mohammed-Brahim B, Brochard P, Dartigues JF, Salamon R. Effets retardés des pesticides sur la santé: état des connaissances épidémiologiques. Rev Epidemiol Sante Publique 1998;46 (02):134-142

8 de Araújo AJ, de Lima JS, Moreira JC, et al. Exposição múltipla a agrotóxicos e efeitos à saúde: estudo transversal em amostra de 102 trabalhadores rurais, Nova Friburgo, RJ. Cien Saude Colet 2007;12(01):115-130

9 Moreira CJ, Jacob SC, Peres F, et al. Avaliação integrada do impacto do uso de agrotóxicos sobre a saúde humana em uma comunidade agrícola de Nova Friburgo, RJ. Cien Saude Colet 2002;7(02): 299-311

10 Faria NMX. Modelo de desenvolvimento, agrotóxicos e saúde: prioridades para uma agenda de pesquisa e ação. Rev Bras Saúde Ocup 2012;7(125):17-50

11 Soares NM. Olhar Interdisciplinar sob a Fumicultura em uma região do Paraná [Internet]. 2013. Available at: http://www.siiepe.ufsc.br/ wp-content/uploads/2013/10/C-Soares.pdf. Accessed Aug 26, 2014

12 Gatto MP, Fioretti M, Fabrizi G, Gherardi M, Strafella E, Santarelli L. Effects of potential neurotoxic pesticides on hearing loss: a review. Neurotoxicology 2014;42:24-32

13 Pacheco-Ferreira H. Epidemiologia das substâncias químicas neurotóxicas. In: Medronho R, Bloch KV, Luiz RR, Werneck GL. Epidemiologia. São Paulo: Atheneu; 2008:577-586

14 World Health Organization, WHOQOL Focus Group Work. Measuring quality of life [Internet]. Geneva: WHO; 1994. Available at: http://www.who.int/mental_health/media/68.pdf. Accessed Aug 26, 2014

15 Fleck MPA. O instrumento de avaliação de qualidade de vida da Organização Mundial da Saúde (WHOQOL-100): características e perspectivas. Cien Saude Colet 2000;5(01):33-38

16 Ware JEJR Jr, Sherbourne CD. The MOS 36-item short-form health survey (SF-36). I. Conceptual framework and item selection. Med Care 1992;30(06):473-483

17 Hua H, Karlsson J, Widén S, Möller C, Lyxell B. Quality of life, effort and disturbance perceived in noise: a comparison between employees with aided hearing impairment and normal hearing. Int J Audiol 2013;52(09):642-649

18 Paim JS. O que é o SUS. Rio de Janeiro: Fiocruz; 2009

19 Ciconelli RM, Ferraz MB, Santos W, Meinão I, Quaresma MR. Tradução para língua portuguesa e validação do questionário genérico de avaliação da qualidade de vida SF-36 (Brasil SF-36). Rev Bras Reumatol 1999;39(03):143-150

20 Dantas RAS, Sawada NO, Malerbo MB. Pesquisas sobre qualidade de vida: revisão da produção científica das universidades públicas do Estado de São Paulo. Rev. Latino-Am. Rev Lationo Am 2003;11 (04):532-538

21 Yamada RS. Saúde e qualidade de vida: um estudo comparativo em duas comunidades rurais no Estado do Paraná [Dissertação]. Pato Branco, Brazil: Universidade Tecnológica Federal do Paraná; 2012:164

22 Garcia EG, Alves Filho JP. Aspectos de prevenção e controle de acidentes no trabalho com agrotóxicos. São Paulo: Fundacentro; 2005

23 Bedor CNG, Ramos LO, Pereira PJ, Rêgo MAV, Pavão AC, Augusto LGS. Vulnerabilidades e situações de riscos relacionados ao uso de agrotóxicos na fruticultura irrigada. Rev Bras Epidemiol 2009;12 (01):39-49

24 Soares WL, Porto MF. Atividade agrícola e externalidade ambiental: uma análise a partir do uso de agrotóxicos no cerrado brasileiro. Cien Saude Colet 2007;12(01):131-143

25 Almeida Filho N. O conceito de saúde: Ponto-cego da epidemiologia? Rev Bras Epidemiol 2000;3(1-3):4-20
26 Czeresnia D, Freitas CM. Promoção da saúde: conceitos, reflexões, tendências. Rio de janeiro: Fiocruz; 2003

$27 \mathrm{Lu} \mathrm{CH}$, Luo ZC, Wang JJ, Zhong JH, Wang PX. Health-related quality of life and health service utilization in Chinese rural-to-urban migrant workers. Int J Environ Res Public Health 2015;12(02): 2205-2214

28 Silva JB, Xavier DS, Barboza MCN, Amestoy SC, Trindade LL, Silva JRS. Fumicultores da zona rural de Pelotas (RS), no Brasil: exposição ocupacional e a utilização de equipamentos de proteção individual (EPI). Saúde Debate 2013;37(97):347-353

29 Troian A, Oliveira SV, Dalcin D, Eichler ML. O uso de agrotóxicos na produção de fumo: algumas percepções de agricultores da comunidade Cândido Brum, no município de Arvorezinha (RS). In: congresso da sociedade brasileira de economia, administração e sociologia rural, 47. Porto Alegre, 2009. Agropecuária, Meio-ambiente e Desenvolvimento Sustentável. Porto Alegre2009

30 Chia EM, Wang JJ, Rochtchina E, Cumming RR, Newall P, Mitchell P. Hearing impairment and health-related quality of life: the Blue Mountains Hearing Study. Ear Hear 2007;28(02):187-195

31 Bess FH. The role of generic health-related quality of life measures in establishing audiological rehabilitation outcomes. Ear Hear 2000;21(4, Suppl)74S-79S

32 Manjabosco CAW, Morata TC, Marques JM. Perfil audiométrico de trabalhadores agrícolas. Int Arch Otorhinolaryngol 2004;8(04): 285-295

33 Azevedo APM. Efeito de produtos químicos e ruído na gênese de perda auditiva ocupacional [Dissertação]. Rio de Janeiro: Fundação Oswaldo Cruz, Escola Nacional de Saúde Pública; 2004:162

34 Morata TC. Chemical exposure as a risk factor for hearing loss. J Occup Environ Med 2003;45(07):676-682

35 Hwang SA, Gomez MI, Sobotova L, Stark AD, May JJ, Hallman EM. Predictors of hearing loss in New York farmers. Am J Ind Med 2001;40(01):23-31

36 Crawford JM, Hoppin JA, Alavanja MCR, Blair A, Sandler DP, Kamel F. Hearing loss among licensed pesticide applicators in the agricultural health study. J Occup Environ Med 2008;50(07): 817-826

37 Lacerda A, Morata TCO. Risco de perda auditiva decorrente da exposição ao ruído associada à agentes químicos: enfoque preventivo. In: Morata TC, Zucki F. (org). Saúde auditiva: avaliação de riscos e prevenção. São Paulo: Plexus; 2010:99-117

38 de Sena TR, Vargas MM, Oliveira CC. Hearing care and quality of life among workers exposed to pesticides. Cien Saude Colet 2013; 18(06):1753-1761

39 Alcarás PA, Larcerda AB, Marques JM. Study of evoked otoacoustic emissions and suppression effect on workers exposed to pesticides and noise. CoDAS 2013;25(06):527-533

40 França DMVR, Bender Moreira Lacerda A, Lobato D, et al. Adverse effects of pesticides on central auditory functions in tobacco growers. Int J Audiol 2017;56(04):233-241

41 Lobato DC. Disfunção auditiva induzida por agrotóxicos em trabalhadores agrícolas do paraná. Paraná [Tese]. Curitiba: Universidade Tuiuti do Paraná; 2015:131

42 Paulilo MI. O Peso do Trabalho Leve. Revista Ciência Hoje- $n^{\circ} 28 /$ 1987. Available at:http://nafa.paginas.ufsc.br/files/2010/09/OPesodoTrabalhoLeve.pdf. Accessed Set 12, 2012

43 Almeida GEG. Fumo: Servidão moderna e violação de direitos humanos. Curitiba [Internet]. SK editoras, 2005. Available at: http://terradedireitos.org.br/acervo/publicacoes/livros/42/ fumo-servidao-moderna-e-a-violacao-dos-direitos-humanos/903. Accessed Set 10, 2012

44 Veiga MM, Silva DM, Veiga LBE, Faria MVC. Pesticide pollution in water systems in a small rural community in Southeast Brazil. Cad Saude Publica 2006;22(11):2391-2399

45 Silva AJM, Novato-Silva E, Faria HP, Pinheiro TM. Agrotóxico e trabalho: uma combinação perigosa para a saúde do trabalhador rural. Cien Saude Colet 2005;10(04):891-903 
46 Soares W, Almeida RM, Moro S. Rural work and risk factors associated with pesticide use in Minas Gerais, Brazil. Cad Saude Publica 2003;19(04):1117-1127

47 ORGANIZAÇÃO PAN-AMERICANA DE SAÚDE - OPAS /ORGANIZAÇÃO MUNDIAL DA SAÚDE - OMS. Manual de vigilância da saúde de populações expostas a agrotóxicos. Brasília1997

48 PARANÁ. Secretaria de Estado da Saúde do Paraná. Superintendência de Vigilância em Saúde. Centro Estadual de Saúde do Trabalhador. Protocolo de Avaliação das Intoxicações Crônicas por Agrotóxicos. Curitiba2013

49 BRASIL. Ministério do Trabalho. Norma Regulamentadora 31-Segurança e Saúde no Trabalho na Agricultura, Pecuária, Silvicultura, Exploração Florestal e Aquicultura. In: Manuais de Legislação Segurança e Medicina do Trabalho. $62^{\circ}$ Ed. São Paulo: Atlas; 2008
50 Lima RG. Implicações Socioeconômicas e Técnico-Sanitárias da Lavoura de Tabaco na Região de Santa Cruz do Sul, RS, Brasil. Sociedade em Debate 2004;10(02):91-109

51 BRASIL. Ministério da Saúde. Secretaria de Vigilância em Saúde. Departamento de Saúde Ambiental e Saúde do Trabalhador. Coordenação Geral de Vigilância em Saúde Ambiental. Modelo de Vigilância em Saúde de Populações Expostas a Agrotóxicos. Brasília2012

52 BRASIL Ministério da Saúde. Secretaria de Vigilância em Saúde. Política nacional de promoção da saúde. Brasília: Ministério da Saúde, 2006. 60 p. - (Série B. Textos Básicos de Saúde) ISBN 85-334-1198-7 Disponível em: http://bvsms.saude.gov.br/ bvs/publicacoes/politica_promocao_saude.pdf. Accessed 09/10/ 2014 